\title{
Comparative Analysis of Innovation and Entrepreneurship Education Curriculum System in Chinese and American Universities ${ }^{1}$
}

\author{
Dan Zhang ${ }^{1, a}$ \\ ${ }^{1}$ School of Economic Management, Jilin Agricultural Science and Technology University , No. 77 \\ hanlin road, jilin economic and technological development zone,Jilin ,Jilin132101 ,China \\ a jiuzhanzhangdan@163.com
}

\begin{abstract}
Keywords: China, America, innovation and entrepreneurship, education, curriculum system Abstract. In term of university innovation and entrepreneurship education, China started late, the curriculum system is not complete yet, while the United States has developed into a world leading position, and its successful experience is worth learning.This paper summarizes its characteristics by studying the curriculum concept, course content, faculty, teaching method of American innovation and entrepreneurship, and then summarizes its successful experience from universities themselves, government policies and social support.Through comparison, this paper finds that education of Chinese innovation and entrepreneurship has some problems.
\end{abstract}

\section{Introduction}

The Chinese ministry of education claimed that common colleges and universities should carry out the entrepreneurship education, which aims to speed up the transformation of the mode of economic development amongst service countries, and build an innovation-oriented country, and the strategy of human resources power, and deepen the reform of the higher education teaching, improve the quality of talent training, and is the important way to promote college students' all-round development, carry out the job creation and encourage entrepreneurship to create more employment opportunities, and the important measure to promote full employment of university graduates. ${ }^{[1]}$ American innovation education started up early and develops mature, it is worth learning from.

\section{Development of Education Course System in American Universities.}

In 1947, the United States opened the first course of innovation and entrepreneurship, 'management of new enterprises'. ${ }^{[2]}$ At present, American innovation and entrepreneurship education has developed to a new level, and American universities' innovation and entrepreneurship education course has spread through the whole country, which start to be on the high-tech entrepreneurship transforming university technological achievements into market products and realizing the combination of high-tech technology and business. The following aspects can be summarized from the examples of American Besson business school and Stanford university:

Objective of Innovation and Entrepreneurship Education Course

Although the objectives of innovation and entrepreneurship education course in American universities are distinctive, the basic goals and the concept of innovation and entrepreneurship education are the same, which is, to cultivate students' awareness of entrepreneurship in different environments, develop students' ability to recognize opportunities and take actions to achieve them, cultivate students' willingness and ability to take risks, develop students' ability to motivate partners toward goals and the courage to take responsibility, develop students' ability to adapt to changes in the entrepreneurial environment, and eventually become leaders of the innovative spirit to explore new situations.

\footnotetext{
${ }^{1}$ Project: the general planning project (GH180466) of Jilin Province education science "the 13th Five-Year Plan"

《Research of Local University Innovation Entrepreneurship Education Curriculum System in New Era》
} 


\section{Structure of Innovation and Entrepreneurship Education Course}

The structure of education course in American colleges and universities is based on different grades and majors, including education course for undergraduates and education course for postgraduates. All courses are divided into compulsory courses and elective courses. Compulsory foundation courses are offered to all students who are interested in the entrepreneurial career, usually in the first year of college, such as the foundation of management and entrepreneurship. Elective courses are offered in the higher grades of the university. For different majors, deeper knowledge and skills are taught, such as entrepreneurship and start-up, entrepreneurship and opportunity. In addition, special knowledge is taught for special fields.

\section{Content of Innovation and Entrepreneurship Education Course}

American college innovation and entrepreneurship courses are divided into the first class and the second class. Since innovation and entrepreneurship courses are generally offered by business schools of various universities, American colleges and universities divide innovation and entrepreneurship courses into business school courses and non-business school courses. Business schools are increasingly cooperating with non-business schools. Business schools and non-business schools jointly teach so as to better integrate the knowledge of innovation and entrepreneurship into the professional knowledge and promote the transformation of technology into business. The second class courses of American college innovation and entrepreneurship courses are mainly completed after class. Business cycle, business association, entrepreneur club, entrepreneurial finance group, entrepreneurship teaching unions are important parts of innovation entrepreneurship education course, different education institutions and students annually via competitions, organized, activities, communication, visit, study, practice, entrepreneurship lecture series and other ways to encourage college students to participate, enhance knowledge and practice their innovation entrepreneurship.

\section{Implementation of Innovation and Entrepreneurship Education Course}

American university innovation and entrepreneurship education courses incorporate many teaching methods, and even the same course is taught through many teaching methods. The retail operation management course uses the practice study method and so on. American universities focus on teacher-student interaction, and the teaching process is consistent with the entrepreneurial activity cycle, so that entrepreneurs can enter the classroom, discuss with students and teachers, and design courses together. In addition, experiential teaching method and project teaching method are widely used in the joint training of students of different majors. The high-quality faculty team is an integral part of the American university innovation and entrepreneurship education. These teachers are generally made up of university professors and business executives with rich entrepreneurial experience. American universities attach great importance to the training and development of entrepreneurial teachers and encourage the entrepreneurial cooperation between schools and enterprises. The abundant start-up capital provided by the government and enterprises is also a strong guarantee for the development of American university innovation and entrepreneurship education.

\section{Current Situation of Education Course System in Chinese Universities}

In 1999, Chinese universities began to develop innovation and entrepreneurship ${ }^{[3]}$. Education courses on innovation and entrepreneurship in Chinese universities are divided into the following aspects:

\section{General Entrepreneurship Courses}

Many universities in China offer general entrepreneurship courses such as "career planning for college students", "employment and entrepreneurship guidance for college students" and "foundation for entrepreneurship" for junior students. In the course of teaching, teachers can impart professional knowledge and entrepreneurship skills to students according to their specialty characteristics and future career nature.

\section{Subject Entrepreneurship Courses}

On the basis of professional education, the entrepreneurship courses and various professional courses are organically integrated to cultivate innovative and entrepreneurial talents with professional 
knowledge and skills in different fields. The majority of universities set the innovation and entrepreneurship course modules according to the specialty characteristics and advantages. Due to the different levels of different universities, the specific courses of entrepreneurship courses are also different, and many courses of entrepreneurship in universities are still in the exploration and start-up stage.

\section{Entrepreneurship Activities}

Entrepreneurship activity courses are similar to the second class entrepreneurship courses in the United States. They mainly focus on students' participation and experiential learning, and cultivate students' entrepreneurship skills and entrepreneurial practice ability, which are determined by the nature and characteristics of entrepreneurship education practice. It mainly includes speeches, lectures, seminars, entrepreneurship skills competition, business plan competition, entrepreneurial internship, experiential entrepreneurship activities and other projects, providing students with plenty of opportunities to practice their entrepreneurial knowledge and ideas.

\section{Recessive Entrepreneurship Courses}

Entrepreneurship center, entrepreneurship training base, science and technology park, business incubator, campus entrepreneurship system, preferential policies and campus entrepreneurship culture construction are all recessive entrepreneurship courses.

\section{Inspiration of Education Curriculum System for Innovation and Entrepreneurship in American Universities to China}

\section{Establish the Scientific Concept of Innovation and Entrepreneurship Education}

The progress in innovation and entrepreneurship education among various Chinese universities is still in the preliminary stage. Many universities only offer basic courses of innovation and entrepreneurship education in response to the situation, but have no systematic course of innovation and entrepreneurship education. The goal of establishment in innovation education course and entrepreneurship in universities is not scientific and perfect. Colleges and universities should integrate innovation awareness and entrepreneurship into students' thoughts and personal qualities, and aim to cultivate talents who can identify entrepreneurial opportunities and undertake entrepreneurial risks and have entrepreneurial ability. Innovation and entrepreneurship should not only encourage college students to start enterprises or companies, but also focus on the future, laying the foundation for the future development of innovation and entrepreneurship in China.

Establish A Complete Course Frame System of Innovation and Entrepreneurship Education At present, there are many problems in the frame of innovation and entrepreneurship education in Chinese universities, such as insufficient variety of courses, narrow coverage and unclear levels. In view of the United States, the lower grades could be taught some professional courses such as "introduction to business" "entrepreneurial mindset" "entrepreneurial spirit to strengthen" "small business management" business model innovation "business writing", which enables students to master basic business theory and knowledge, and train the student's basic ability, for more possibilities in future business study practice.

\section{Improve the Content of Innovation and Entrepreneurship Education Course}

The contents of education courses in Chinese universities are similar, unprofessional and not practical. Entrepreneurial education has typical interdisciplinary features, and the intersection and penetration of multiple disciplines play an important role in expanding students' knowledge and cultivating students' creative thinking. According to the American experience, Chinese colleges and universities can offer courses in economics, management, finance, accounting and law in different majors. Through the interdisciplinary integration, students can master more comprehensive entrepreneurship knowledge. The course content should be directed to specific operations and specific projects, so that students can better convert theory into practice. 


\section{Improve the Implementation Method of Innovation and Entrepreneurship Education Course} In class, we should integrate various methods such as case analysis, group discussion, business plan writing, etc. On another hand, in extracurricular practice we should adopt American experience, and integrate the methods such as competition, entrepreneurial activity, entrepreneurial internship, social investigation and simulation entrepreneurship into practice. Qualified colleges and universities can provide students with more authentic entrepreneurial platforms, such as science and technology parks and business incubators, so that students can participate in real entrepreneurial environment and entrepreneurship activities or projects under the platform, get practical entrepreneurial experience and feelings, and improve their entrepreneurial ability.

\section{Conclusions}

In the development of China's innovation and entrepreneurship education, teachers with rich start-up experience, abundant start-up support funds and great support and guidance from the government and universities are required to constantly take innovation and entrepreneurship education to a new level.

\section{Acknowledgements}

Thanks for the general planning project (GH180466) of Jilin Province education science "the 13th Five-Year Plan" 《Research of Local University Innovation Entrepreneurship Education Curriculum System in New Era》.

\section{References}

[1] Notice on basic teaching requirements (trial) of entrepreneurship in ordinary undergraduate schools 2012 Ministry of education of the People's Republic of China .

[2] Wei Ye. Model analysis of American innovation and entrepreneurship education course organization -- a case study of Babson school of business, Stanford University and the university of Missouri .China: Journal of Chongqing radio and television university.(2017).p30-36.

[3] Weilin Cao and Decai Li. Entrepreneurship of Chinese Universities education. China: Modern education science (2002).p155-157. 